\title{
Variability of above-ground litter inputs alters soil physicochemical and biological processes: a meta-analysis of litterfall-manipulation experiments
}

\author{
S. Xu ${ }^{1,2}$, L. L. Liu ${ }^{2}$, and E. J. Sayer ${ }^{3}$ \\ ${ }^{1}$ University of Chinese Academy of Sciences, Yuquan Road, Beijing 100049, China \\ ${ }^{2}$ State Key Laboratory of Vegetation and Environmental Change, Institute of Botany, Chinese Academy of Sciences, \\ Xiangshan, Beijing 100093, China \\ ${ }^{3}$ Department of Environment, Earth \& Ecosystems, The Open University, Walton Hall, Milton Keynes, MK7 6AA, UK \\ Correspondence to: L. Liu (lingli.liu@ibcas.ac.cn)
}

Received: 5 February 2013 - Published in Biogeosciences Discuss.: 14 March 2013

Revised: 29 September 2013 - Accepted: 21 October 2013 - Published: 19 November 2013

\begin{abstract}
Global change has been shown to alter the amount of above-ground litter inputs to soil greatly, which could cause substantial cascading effects on below-ground biogeochemical cycling. Despite extensive study, there is uncertainty about how changes in above-ground litter inputs affect soil carbon and nutrient turnover and transformation. Here, we conducted a meta-analysis on 70 litter-manipulation experiments in order to assess how changes in above-ground litter inputs alter soil physicochemical properties, carbon dynamics and nutrient cycles. Our results demonstrated that litter removal decreased soil respiration by $34 \%$, microbial biomass carbon in the mineral soil by $39 \%$ and total carbon in the mineral soil by $10 \%$, whereas litter addition increased them by 31,26 and $10 \%$, respectively. This suggests that greater litter inputs increase the soil carbon sink despite higher rates of carbon release and transformation. Total nitrogen and extractable inorganic nitrogen in the mineral soil decreased by 17 and $30 \%$, respectively, under litter removal, but were not altered by litter addition. Overall, litter manipulation had a significant impact upon soil temperature and moisture, but not soil $\mathrm{pH}$; litter inputs were more crucial in buffering soil temperature and moisture fluctuations in grassland than in forest. Compared to other ecosystems, tropical and subtropical forests were more sensitive to variation in litter inputs, as altered litter inputs affected the turnover and accumulation of soil carbon and nutrients more substantially over a shorter time period. Our study demonstrates that although the magnitude of responses differed greatly among
\end{abstract}

ecosystems, the direction of the responses was very similar across different ecosystems. Interactions between plant productivity and below-ground biogeochemical cycling need to be taken into account to predict ecosystem responses to environmental change.

\section{Introduction}

Above-ground litterfall is one of the most important components of carbon and nutrient cycling, and the litter layer regulates soil microclimate by forming a buffering interface between the soil surface and the atmosphere (Sayer, 2006). Terrestrial ecosystems are undergoing simultaneous changes in climate and biogeochemical cycles, and those changes could affect plant net primary production (NPP) positively or negatively. Changes such as elevated $\mathrm{CO}_{2}$ (King et al., 2005), nitrogen deposition (Xia and Wan, 2008) and temperature increases (Raich et al., 2006) were found to enhance plant productivity, whereas elevated $\mathrm{O}_{3}$ (Liu et al., 2005), drought (Zhao and Running, 2010) and acid deposition (Irving and Miller, 1981) generally decreased productivity. These changes in primary production could alter both the quality and quantity of above-ground litter inputs to soil (Liu et al., 2005), and therefore physical, chemical and biological properties of the litter layer. In addition, extreme events, the frequency of which may increase in future, could also lead to sudden and dramatic changes in litter inputs, such as a large 
increase in above-ground litterfall after hurricanes or severe storms (Ostertag et al., 2003), or rapid loss of the litter layer after wildfires (Wardle et al., 2003).

As one of the most important pathways for carbon and nutrient fluxes to the soil, changes in above-ground litter inputs could lead to cascading effects on below-ground biogeochemical processes. Although changes in above-ground litter inputs have been observed in numerous global change manipulation experiments in multiple ecosystems, most of those studies found that total soil carbon (C) content was generally unchanged (Baer and Blair, 2008; Talhelm et al., 2009, but see Fornara and Tilman, 2012). Several mechanisms have been proposed to explain why soil $\mathrm{C}$ showed small changes even when above-ground litter inputs were greatly altered. One possible explanation is that soil $\mathrm{C}$ may be altered by litter inputs, but the changes are too small to be detected in the large and heterogeneous soil C pool (Hungate et al., 1996). A change in the strength of priming effects is another possible reason: high litter inputs could cause greater priming effects, and the increase in new soil $\mathrm{C}$ derived from the litter may be offset by the decomposition of older soil C (Sayer et al., 2011). Soil carbon saturation is also a plausible theory to explain the lack of changes in soil $\mathrm{C}$ content in response to varying amounts of litter inputs. The theory states that the capacity of soil to stabilize organic $\mathrm{C}$ has an upper limit, which is determined by soil physical, chemical and biochemical characteristics (Six et al., 2002a).

An emerging view suggests that the majority of organic $\mathrm{C}$ in soil is derived from rhizodeposition, and above-ground litter inputs have a limited influence on soil C storage (Schmidt et al., 2011). The lack of changes in total soil $\mathrm{C}$ has sparked a debate about whether alterations in above-ground litter production as a result of global change will impact upon longterm soil C storage. Quantification of the contribution of above-ground litter to soil $\mathrm{C}$ sequestration and nutrient cycling is therefore needed to assess the importance of aboveground litter in below-ground processes.

A large number of litter-manipulation studies, in which litter is experimentally added or removed, have been conducted since the first experiments in the 1850s (Sayer, 2006). The information we draw from this rich research history of litter-manipulation experiments could help us better understand how above-ground litter inputs affect below-ground processes, and therefore the mechanisms regulating the potential of soil to sequester additional C. Below-ground processes, such as soil respiration, microbial activity, and soil C formation are simultaneously influenced by litter inputs, and these processes intrinsically interact with each other (Chapin et al., 2011). To assess the consequences of above-ground litter inputs on soil physical, chemical and biochemical processes quantitatively, we conducted a meta-analysis of littermanipulation experiments from multiple terrestrial ecosystems. Changes in litter productivity may be accompanied by changes in litter biochemistry, and the two interact with each other in biogeochemical processes (Liu et al., 2009). How- ever, because of the limited data availability on changes in litter biochemistry, this study focused on the impact of changes in litter productivity on below-ground $\mathrm{C}$ and nutrient cycling.

\section{Methods}

\subsection{Data selection}

A comprehensive literature search, covering relevant peerreviewed articles and dissertations from 1950 to 2013, was conducted using the databases of Web of Science and ProQuest. We also cross-checked the references of the relevant articles to identify other potential book chapters and peerreviewed reports. Only data from in situ litter-manipulation experiments were included in our data set. Studies were excluded if they were conducted in a controlled laboratory setting (e.g. Liu et al., 2009), or the additional carbon was supplied as specific organic compounds such as glucose (e.g. Park and Matzner, 2006) or cellulose (e.g. Fontaine et al., 2004). When data from the same site and treatments were presented in multiple publications, we used the data from the most recent publications. Similarly, when data from multiple years were given, we only used data from the most recent year. Litter-manipulation experimental sites were from multiple climatic zones, including arctic, boreal, temperate and (sub-)tropical regions (See details in Appendix B in the Supplement). Here, "(sub-)tropical" includes both tropical and sub-tropical regions.

Four categories of data related to below-ground biotic and abiotic properties were extracted from the literature of in situ litter-manipulation experiments: (1) soil surface physical and chemical properties, including soil temperature, soil moisture and soil $\mathrm{pH}$; (2) microbial responses, including microbial biomass carbon (MBC) and microbial biomass nitrogen (MBN); (3) C fluxes and pools, including soil respiration, total carbon (C) and dissolved organic carbon (DOC); and (4) nutrient fluxes and pools, including total nitrogen $(\mathrm{N}), \mathrm{C}: \mathrm{N}$ ratios $(\mathrm{C}: \mathrm{N})$, dissolved organic nitrogen $(\mathrm{DON})$, extractable inorganic nitrogen (EIN), and extractable phosphorus $(\mathrm{P})$. Where relevant, we distinguished between litter layer and mineral soil for all variables, but results were only reported where sufficient data points were available (i.e. $n \geq 4$ ). In our data set, litter layer data were all from studies conducted in boreal forest or temperate forest and included forest floor (Fisk and Fahey, 2001), O horizon (Nadelhoffer et al., 2004), O layer (Fröberg et al., 2005), epihumus subhorizon (Dzwonko and Gawronski, 2002), and humus horizon (Dzwonko and Gawronski, 2002). Mineral soil in our data set is defined as the soil beneath the litter layer, or the topsoil from ecosystems such as grassland and (sub-)tropical forest. The sampling depth in the mineral soil ranged from 1 to $40 \mathrm{~cm}$, with the majority of the data collected in the top $10 \mathrm{~cm}$. When measurements were conducted in different mineral soil depths, we only used the data reported for 
Table 1. Effects of litter removal and litter addition on soil physicochemical properties of different ecosystems. For each response variables, the responses of the ecosystems denoted by different superscript letter differed significantly $(P<0.05)$. RR: the mean response ratio; $95 \%$ CI: $95 \%$ confident intervals; n: no. observations; “-”: no data.

\begin{tabular}{|c|c|c|c|c|c|c|c|c|}
\hline \multirow[b]{2}{*}{ Response variable } & \multirow[b]{2}{*}{ Soil layer } & \multirow[b]{2}{*}{ Group } & \multicolumn{3}{|c|}{ Litter removal } & \multicolumn{3}{|c|}{ Litter addition } \\
\hline & & & $\mathrm{RR}$ & $95 \% \mathrm{CI}$ & $n$ & $\mathrm{RR}$ & $95 \% \mathrm{CI}$ & $n$ \\
\hline \multirow[t]{3}{*}{ Soil temperature } & \multirow[t]{3}{*}{ Mineral soil } & All & 1.04 & $1.01-1.07$ & 21 & 0.97 & $0.93-1.00$ & 11 \\
\hline & & (Sub-)tropical forest & $0.99^{\mathrm{a}}$ & $0.98-1.00$ & 11 & $1.00^{\mathrm{a}}$ & $0.99-1.01$ & 4 \\
\hline & & Grassland & $1.10^{\mathrm{b}}$ & $1.03-1.17$ & 6 & $0.92^{\mathrm{b}}$ & $0.86-0.97$ & 4 \\
\hline \multirow[t]{5}{*}{ Soil moisture } & \multirow[t]{5}{*}{ Mineral soil } & All & 0.90 & $0.84-0.95$ & 35 & 1.04 & $0.99-1.09$ & 33 \\
\hline & & Temperate forest & $0.85^{\mathrm{a}}$ & $0.68-1.00$ & 7 & $0.97^{\mathrm{a}}$ & $0.90-1.05$ & 10 \\
\hline & & (Sub-)tropical forest & $0.93^{\mathrm{a}}$ & $0.88-0.97$ & 19 & $1.01^{\mathrm{a}}$ & $0.95-1.06$ & 6 \\
\hline & & Grassland & $0.82^{\mathrm{a}}$ & $0.66-0.95$ & 6 & $1.13^{b}$ & $1.06-1.20$ & 11 \\
\hline & & Shrubland & - & - & - & $1.05^{\mathrm{ab}}$ & $0.92-1.20$ & 6 \\
\hline \multirow[t]{4}{*}{ Soil pH } & \multirow[t]{2}{*}{ Litter layer } & All & 1.00 & $0.97-1.03$ & 9 & 1.02 & $1.01-1.02$ & 2 \\
\hline & & Boreal forest & 1.00 & $0.96-1.05$ & 6 & - & - & - \\
\hline & \multirow[t]{2}{*}{ Mineral soil } & All & 1.00 & $0.98-1.02$ & 11 & 1.04 & $0.99-1.09$ & 7 \\
\hline & & (Sub-)tropical forest & 1.02 & $1.00-1.03$ & 8 & - & - & - \\
\hline
\end{tabular}

the uppermost depth (e.g. Tian et al., 2010). When data were graphically presented, we extracted the numerical values by digitizing the figures using Engauge Digitizer (Free Software Foundation, Inc., Boston, MA, USA).

\subsection{Meta-analysis}

The data were analysed using the meta-analysis described by Hedges et al. (1999). The effect size of littermanipulation treatment for each individual observation was estimated by the natural log of the response ratio (RR): $\ln$ $\mathrm{RR}=\ln \left(\bar{X}_{\mathrm{t}} / \bar{X}_{\mathrm{c}}\right)$, where $\bar{X}_{\mathrm{c}}$ is the control mean, and $\bar{X}_{\mathrm{t}}$ is the treatment mean. The average response ratio (RR) was calculated using the mixed model of the meta-analytical software METAWIN (Sinauer Associates, Inc., Sunderland, MA, USA). The variance of the mean effect size was calculated using resampling techniques (Adams et al., 1997). If the lower bound of the $95 \% \mathrm{CI}$ of RR was larger than 1, then the response was significantly positive at $P<0.05$. If the upper bound of the $95 \% \mathrm{CI}$ of RR was smaller than 1, then the response was significantly negative at $P<0.05$. For each investigated parameter, a subgroup analysis was conducted to assess whether the magnitudes of effects differed across ecosystem types, soil depths or treatment duration. Although there is no accepted minimum number of studies that are required for a meta-analysis, we adopted the criteria for systematic review by Fu et al. (2011) in which each subgroup should have a minimum of four studies. We therefore present results for separate ecosystems only where sufficient observations were available in more than one subgroup. Total heterogeneity $\left(Q_{\mathrm{T}}\right)$ was partitioned into within-group $\left(Q_{\mathrm{W}}\right)$ and between-group $\left(Q_{\mathrm{B}}\right)$ heterogeneities. According to Hedges et al. (1999), a significant $Q_{\mathrm{B}}$ indicates that the response ratios differ among groups. Means of the groups were considered significantly different if their $95 \%$ CI did not overlap.

\subsection{Regression analysis}

Most studies included in our data set reported the amounts of litter added or removed. Data from both litter removal and litter addition experiments were grouped for each parameter, with negative values representing litter removal and positive values representing litter addition. The correlation between the response ratio (RR) of a biogeochemical parameter and the amounts of litter was determined by linear regression. All regression analyses were conducted using SAS software (SAS Institute Inc., Cary, NC, USA).

\section{Results}

In total, 440 observations were extracted from 70 publications, including ecosystems such as boreal forest ( 3 publications), temperate forest (20 publications), (sub-)tropical forest (20 publications), grassland ( 22 publications) and shrubland (5 publications; Appendix B). Across all studies, the mean annual air temperature ranged from -4.2 to $27^{\circ} \mathrm{C}$, mean annual precipitation from 315 to $5000 \mathrm{~mm}$, and the experiments ranged in duration from half a year to $20 \mathrm{yr}$. Site characteristics for each study are given in Appendix B in the Supplement.

\subsection{Physical and chemical properties of the litter layer and mineral soil}

Across all ecosystems, litter removal increased the temperature of the mineral soil by $4 \%$, and litter addition decreased it by $3 \%$ (Table 1 ). The response of soil temperature to litter manipulation differed among ecosystems: in grasslands, soil temperature increased with litter removal and decreased with litter addition, whereas in (sub-)tropical forest 
Table 2. Effects of litter removal and litter addition on soil carbon cycling parameters of different ecosystems, where MBC is microbial biomass carbon, $\mathrm{MBN}$ is microbial biomass nitrogen, and DOC is dissolved organic carbon. For each response variables, the responses of the ecosystems denoted by different superscript letter differed significantly $(P<0.05)$.

\begin{tabular}{|c|c|c|c|c|c|c|c|c|}
\hline \multirow[b]{2}{*}{ Response variable } & \multirow[b]{2}{*}{ Soil layer } & \multirow[b]{2}{*}{ Group } & \multicolumn{3}{|c|}{ Litter removal } & \multicolumn{3}{|c|}{ Litter addition } \\
\hline & & & $\mathrm{RR}$ & $95 \% \mathrm{CI}$ & $n$ & $\mathrm{RR}$ & $95 \% \mathrm{CI}$ & $n$ \\
\hline \multirow[t]{6}{*}{$\mathrm{MBC}$} & Litter layer & All & 0.77 & $0.54-0.96$ & 3 & 1.29 & $1.00-1.68$ & 2 \\
\hline & Mineral soil & All & 0.61 & $0.48-0.76$ & 17 & 1.26 & $1.17-1.37$ & 23 \\
\hline & & Temperate forest & $0.71^{\mathrm{a}}$ & $0.36-1.07$ & 4 & - & - & - \\
\hline & & (Sub-)tropical forest & $0.51^{\mathrm{a}}$ & $0.40-0.66$ & 10 & - & - & - \\
\hline & & Grassland & - & - & - & $1.34^{\mathrm{a}}$ & $1.22-1.49$ & 15 \\
\hline & & Shrubland & - & - & - & $1.12^{\mathrm{b}}$ & $1.05-1.17$ & 4 \\
\hline \multirow[t]{2}{*}{ MBN } & Mineral soil & All & 0.86 & $0.77-0.96$ & 5 & 1.46 & $1.21-1.77$ & 10 \\
\hline & & Grassland & - & - & - & 1.82 & $1.57-2.11$ & 6 \\
\hline \multirow[t]{4}{*}{ Soil respiration } & & All & 0.66 & $0.59-0.73$ & 22 & 1.31 & $1.21-1.43$ & 22 \\
\hline & & Temperate forest & $0.67^{\mathrm{a}}$ & $0.58-0.75$ & 5 & $1.38^{\mathrm{a}}$ & $1.16-1.71$ & 4 \\
\hline & & (Sub-)tropical forest & $0.65^{\mathrm{a}}$ & $0.55-0.75$ & 14 & $1.20^{\mathrm{a}}$ & $1.02-1.44$ & 6 \\
\hline & & Grassland & - & - & - & $1.35^{\mathrm{a}}$ & $1.21-1.48$ & 12 \\
\hline \multirow[t]{3}{*}{ DOC } & Litter layer & Temperate forest & 0.78 & $0.67-0.87$ & 7 & 1.47 & $1.34-1.64$ & 9 \\
\hline & Mineral soil & All & 0.69 & $0.53-0.93$ & 7 & 1.07 & $0.76-1.40$ & 6 \\
\hline & & Temperate forest & 0.81 & $0.59-1.09$ & 5 & 0.94 & $0.63-1.39$ & 4 \\
\hline \multirow[t]{5}{*}{ Total C } & Litter layer & All & 0.95 & $0.94-0.96$ & 2 & 1.09 & $1.04-1.17$ & 3 \\
\hline & Mineral soil & All & 0.90 & $0.83-0.98$ & 19 & 1.10 & $1.01-1.20$ & 18 \\
\hline & & Temperate forest & $0.91^{\mathrm{a}}$ & $0.77-1.09$ & 7 & $1.10^{\mathrm{a}}$ & $0.97-1.28$ & 10 \\
\hline & & (Sub-)tropical forest & $0.80^{\mathrm{a}}$ & $0.74-0.88$ & 4 & - & - & - \\
\hline & & Grassland & $0.94^{\mathrm{a}}$ & $0.86-1.06$ & 8 & $1.03^{\mathrm{a}}$ & $0.99-1.10$ & 6 \\
\hline
\end{tabular}

litter removal reduced soil temperature but litter addition had no effect (Table 1).

Across all studies, litter removal decreased soil moisture in the mineral soil by $10 \%$ (Table 1 ), whereas litter addition had no significant effect (Table 1). However, when the data were analysed for each ecosystem type separately, litter addition increased moisture in the mineral soil in grassland by an average of $13 \%$ but had no significant effect in forests or shrubland (Table 1).

Overall, litter manipulation did not affect $\mathrm{pH}$ in the litter layer or the mineral soil (Table 1).

\subsection{Microbial responses}

Overall, litter removal reduced $\mathrm{MBC}$ in the mineral soil by $39 \%$. However, this decrease was only significant in (sub-)tropical forest (Table 2). Litter addition increased MBC in the mineral soil by an average of $26 \%$, with grassland showing a greater increase than shrubland (Table 2).

Litter removal decreased MBN in the mineral soil by an average of $14 \%$, and litter addition significantly increased MBN in the mineral soil by an average of $46 \%$ across all ecosystem types (Table 2).

\subsection{C cycling}

Soil respiration rates decreased with litter removal by an average of $34 \%$ across all studies and increased by an average of $31 \%$ with litter addition (Table 2). The response ratio of soil respiration rates was positively correlated with the amounts of litter added or removed (Fig. 1a, $R^{2}=0.65$, $P<0.01$ ) and with the response ratio of MBC (see Fig. A3 in the Supplement, $R^{2}=0.66, P<0.01$ ).

Litter removal reduced DOC concentrations in the litter layer by $22 \%$ and in the mineral soil by $31 \%$ (Table 2 ). Litter addition increased DOC concentrations in the litter layer by an average of $47 \%$, but had no significant effect on DOC concentrations in the mineral soil (Table 2).

Overall, litter removal decreased total $\mathrm{C}$ in the mineral soil by $10 \%$, and, correspondingly, litter addition increased it by $10 \%$ (Table 2 ). When the data were analysed by ecosystem type, there was a significant decrease in total $\mathrm{C}$ of the mineral soil in response to litter removal in (sub-)tropical forest, but no effect in temperate forest and grassland. There was no clear effect of litter addition on total $\mathrm{C}$ in the mineral soil either in temperate forest or grassland and insufficient data for (sub-)tropical forests (Table 2). The effect of litter manipulation on total $\mathrm{C}$ in the mineral soil was strongly influenced by soil depth. When data were divided into different sampling depths, total $\mathrm{C}$ content in the top $5 \mathrm{~cm}$ of the mineral soil was $31 \%$ higher under litter addition, but there was no 
Table 3. Effects of litter removal and litter addition on soil nutrient cycling parameters of different ecosystems, where DON is dissolved organic nitrogen and EIN is extractable inorganic nitrogen. For each response variables, the responses of the ecosystems denoted by different superscript letter differed significantly $(P<0.05)$.

\begin{tabular}{|c|c|c|c|c|c|c|c|c|}
\hline \multirow[b]{2}{*}{ Response variable } & \multirow[b]{2}{*}{ Soil layer } & \multirow[b]{2}{*}{ Group } & \multicolumn{3}{|c|}{ Litter removal } & \multicolumn{3}{|c|}{ Litter addition } \\
\hline & & & $\mathrm{RR}$ & $95 \% \mathrm{CI}$ & $n$ & RR & $95 \% \mathrm{CI}$ & $n$ \\
\hline \multirow[t]{5}{*}{$\mathrm{C}: \mathrm{N}$ ratio } & \multirow[t]{3}{*}{ Litter layer } & All & 0.99 & $0.94-1.03$ & 9 & 1.24 & $1.04-1.66$ & 4 \\
\hline & & Boreal forest & 0.98 & $0.91-1.05$ & 6 & - & - & - \\
\hline & & Temperate forest & - & - & - & 1.24 & $1.04-1.66$ & 4 \\
\hline & \multirow[t]{2}{*}{ Mineral soil } & All & 0.94 & $0.89-0.99$ & 8 & 1.03 & $0.99-1.08$ & 13 \\
\hline & & Temperate forest & 0.95 & $0.87-1.02$ & 5 & 1.01 & $0.95-1.07$ & 7 \\
\hline \multirow[t]{5}{*}{ Total N } & Litter layer & All & 0.92 & $0.92-0.92$ & 2 & 0.84 & $0.62-1.02$ & 3 \\
\hline & \multirow{4}{*}{ Mineral soil } & All & 0.83 & $0.77-0.88$ & 12 & 1.04 & $0.95-1.13$ & 19 \\
\hline & & Temperate forest & $0.83^{\mathrm{a}}$ & $0.73-0.93$ & 7 & $1.03^{\mathrm{a}}$ & $0.90-1.20$ & 10 \\
\hline & & (Sub-)tropical forest & $0.80^{\mathrm{a}}$ & $0.79-0.81$ & 4 & - & - & - \\
\hline & & Shrubland & - & - & - & $0.93^{\mathrm{a}}$ & $0.83-1.02$ & 4 \\
\hline \multirow[t]{3}{*}{ DON } & Litter layer & Temperate forest & 1.04 & $0.79-1.27$ & 3 & 1.76 & $1.47-2.09$ & 3 \\
\hline & \multirow[t]{2}{*}{ Mineral soil } & All & 1.00 & $0.78-1.25$ & 6 & 1.06 & $0.81-1.31$ & 11 \\
\hline & & Temperate forest & 1.00 & $0.79-1.25$ & 6 & 1.04 & $0.76-1.35$ & 9 \\
\hline \multirow[t]{4}{*}{ EIN } & Litter layer & Temperate forest & 1.50 & $1.14-1.97$ & 4 & 1.25 & $0.82-1.90$ & 5 \\
\hline & \multirow[t]{3}{*}{ Mineral soil } & All & 0.70 & $0.52-0.96$ & 12 & 0.76 & $0.57-1.01$ & 10 \\
\hline & & Temperate forest & $1.21^{\mathrm{a}}$ & $0.72-1.77$ & 4 & 0.70 & $0.50-0.98$ & 8 \\
\hline & & (Sub-)tropical forest & $0.47^{\mathrm{b}}$ & $0.38-0.59$ & 6 & - & - & - \\
\hline \multirow[t]{2}{*}{ Extractable P } & \multirow[t]{2}{*}{ Mineral soil } & All & 0.82 & $0.64-1.03$ & 7 & 1.16 & $0.98-1.47$ & 5 \\
\hline & & (Sub-)tropical forest & 0.71 & $0.54-0.94$ & 4 & - & - & - \\
\hline
\end{tabular}

significant increase at other soil depths (see Table A1 in the Supplement).

\subsection{Nutrient cycling}

The $\mathrm{C}: \mathrm{N}$ ratio of the litter layer did not change with litter removal, but increased significantly with litter addition (Table 3). Overall, the $\mathrm{C}: \mathrm{N}$ ratio of the mineral soil decreased by $6 \%$ following litter removal, whereas litter addition had no significant effect (Table 3).

Across all ecosystems, litter removal reduced total $\mathrm{N}$ in the mineral soil by $17 \%$. Litter addition had no significant impact on total $\mathrm{N}$ in the mineral soil (Table 3), and neither litter removal nor litter addition affected DON in the mineral soil (Table 3). Litter removal increased EIN in the litter layer by $50 \%$ and decreased EIN in the mineral soil by $30 \%$ (Table 3), whereas litter addition had no significant effect (Table 3).

Overall, neither litter removal nor litter addition affected extractable $\mathrm{P}$ in the mineral soil (Table 3 ).

\subsection{The effects of litter-manipulation levels on below-ground processes}

Regression analysis showed that the RR of soil respiration, MBC in the mineral soil, total $\mathrm{C}$ in the litter layer and mineral soil, total $\mathrm{N}$ in the mineral soil, DOC in the litter layer and $\mathrm{C}: \mathrm{N}$ ratios in the mineral soil all showed a positive linear relationship with litter inputs (Fig. 1, Table A3 and Fig. A2 in the Supplement).

\section{Discussion}

Global change has been shown to alter plant productivity significantly, which leads to increased or decreased aboveground litter inputs to soil with presumed knock-on effects for soil C stocks and nutrient supply. Despite this, relatively few litter-manipulation experiments have specifically examined how variation in litter inputs affects below-ground processes in the context of global environmental change (e.g. Liu et al., 2009; Sayer et al., 2011). Our systematic synthesis of litter-manipulation experiments aimed to improve our understanding of the responses of below-ground processes to varying inputs of above-ground litter under global change. The magnitude of responses to litter manipulation varied among ecosystems, and this was likely partly influenced by the number of data points available. Nevertheless, with few exceptions, the direction of the responses was the same regardless of ecosystem type (Fig. 1).

\subsection{Physical and chemical properties of the litter layer and mineral soil}

The litter layer acts as a protective interface between atmosphere and soil by regulating soil physicochemical conditions such as soil temperature, moisture and $\mathrm{pH}$ (Sayer, 

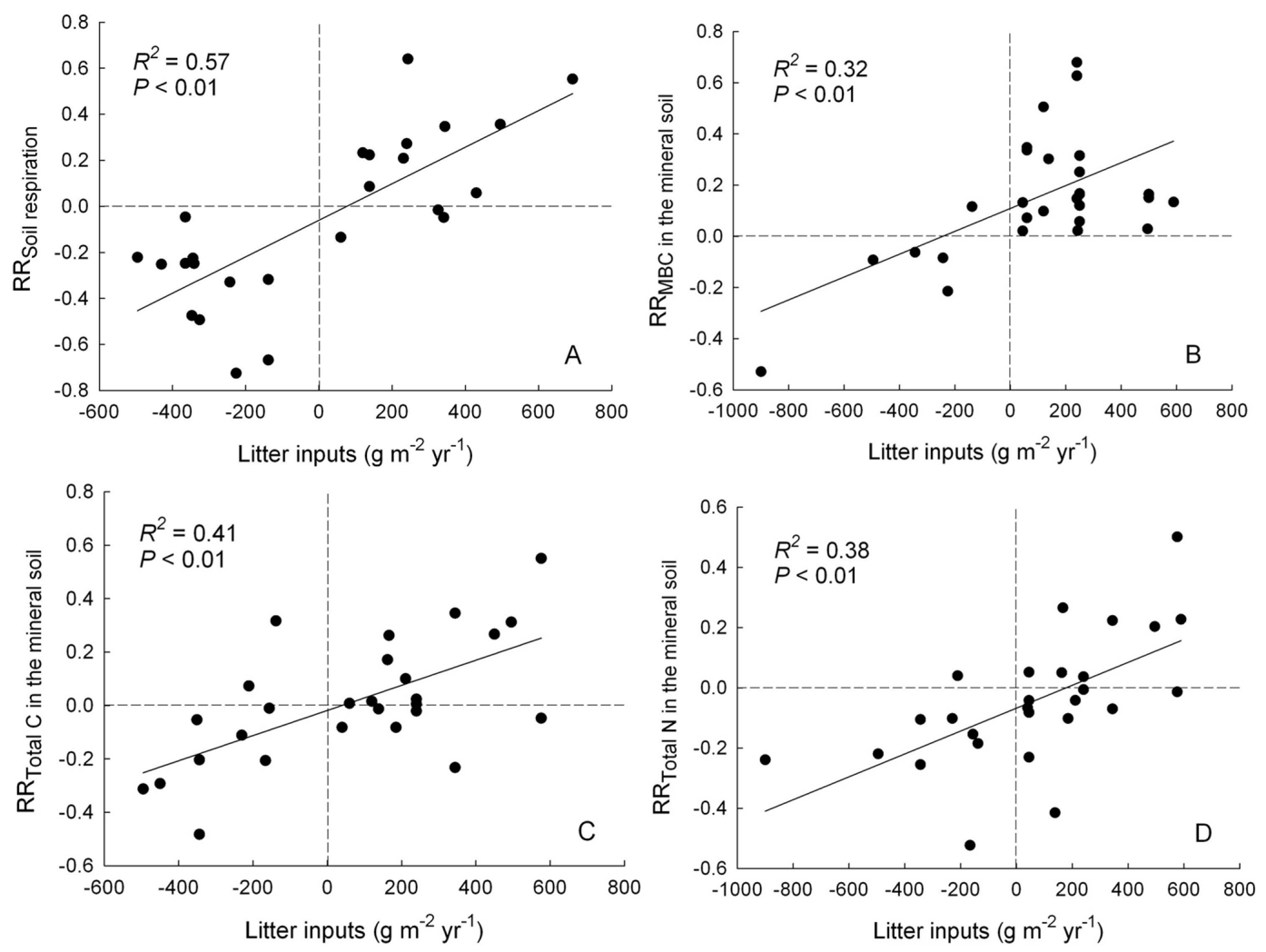

Fig. 1. Relationships between the amounts of litter manipulation and the response ratios (RRs) of (A) soil respiration, (B) microbial biomass carbon (MBC), (C) total carbon (C) and (D) total nitrogen $(\mathrm{N})$ in the mineral soil.

2006). Our analysis demonstrates that the temperature of the mineral soil increased under litter removal and decreased under litter addition, whereas the water content of the mineral soil decreased under litter removal but did not respond to litter addition. Litter inputs were more important in buffering mineral soil temperature and moisture fluctuations in grassland than in forest (Table 1). Forest canopies can intercept solar heat and precipitation by the large surface area of branches and foliage (Lowman and Schowalter, 2012), whereas the vegetation in grassland has a much shorter and simpler structure, and has limited capacity to intercept solar radiation and precipitation compared to the forest canopy. Grasslands therefore rely more on surface litter to maintain a favourable soil environment (Amatangelo et al., 2008).

Litter inputs may change soil $\mathrm{pH}$ via changing the release of organic acids or the supply of exchangeable base cations during the processes of litter decomposition, but we found that litter manipulation had a small impact on soil $\mathrm{pH}$. Previous work has shown that the direction of changes in soil $\mathrm{pH}$ with litter manipulation may depend on litter type and initial soil pH (Sayer, 2006), but at present there are insufficient data to analyse this quantitatively.

\subsection{Microbial responses}

It is generally accepted that microbes are C-limited, and fresh litter can increase soil microbial biomass and activity (Fisk and Fahey, 2001). We found that litter addition significantly increased $\mathrm{MBC}$ in the mineral soil, whereas litter removal caused a general decrease in MBC (Fig. 1, Table 2). It is likely that this result was largely shaped by the response of (sub-)tropical forests where microbes may be more reliant on carbon supply from fresh litter than in other ecosystems. The mean residence time (MRT) of surface litter in tropical forest is 0.25 to $1 \mathrm{yr}$, compared to $4-16 \mathrm{yr}$ MRT in temperate forest (Olson, 1963), and there is little or no build-up of an organic forest floor in lowland tropical forests (Wieder and Wright, 1995). Litter removal could therefore induce a greater decline in microbial activities in (sub-)tropical forest because microbes have only limited access to organic $\mathrm{C}$ from other sources. The observed reduction in soil-extractable $\mathrm{P}$ under litter removal (Table 3) may also contribute to the decrease in MBC, as microbial utilization of soil organic carbon is thought to be P-limited in tropical forests (Cleveland et al., 2002). Thus, litter removal decreased the above-ground $C$ supply for microbial growth, and simultaneously decreased soil-extractable P in (sub-)tropical forests (Table 3), which may also limit microbial decomposition of old soil organic carbon. 


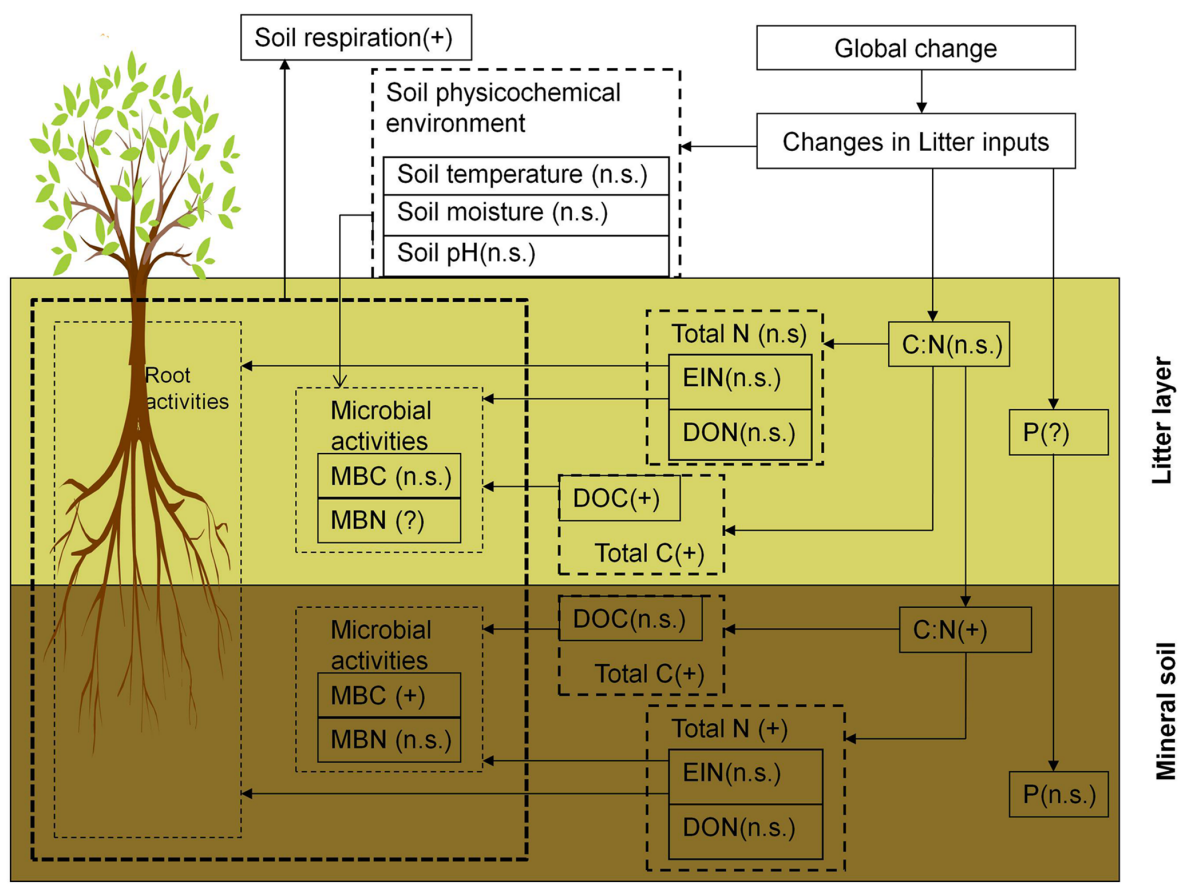

Fig. 2. The responses of soil carbon and nutrient cycling to changes in litter inputs, where MBC is microbial biomass carbon, MBN microbial biomass nitrogen, DOC dissolved organic carbon, DON dissolved organic nitrogen, EIN extractable inorganic nitrogen and P is extractable phosphorus. The relationship between the response ratio of each parameter and the quantity of litter inputs is shown in parentheses. "+" indicates a significant positive linear correlation; “-” indicates a significant negative linear correlation; n.s. is non-significant; "?" indicates an unknown relationship because of data limitations.

Microbial biomass is the living microbial component of the soil, and can be used as a bio-indicator for evaluating soil organic matter turnover rates (Wardle, 1992). We found that the RRs of MBC and soil respiration were positively correlated, and MBC explained $66 \%$ of the variance in changes in soil respiration (Fig. A3 in the Supplement). Litter manipulation also has the potential to affect root respiration by altering root biomass; however, Sayer and Tanner (2010) showed that the contribution of root respiration to total below-ground respiration decreased with litter addition, and the strong correlation between the Rrs of MBC and soil respiration in our analysis suggests that the changes in soil respiration under litter manipulation are largely controlled by $\mathrm{CO}_{2}$ efflux from heterotrophic respiration during litter decomposition.

\subsection{C cycling}

\subsubsection{DOC}

We were only able to assess the responses of DOC to litter manipulation for temperate forests, as there were insufficient available data for other ecosystems. Our results suggested that although DOC of the litter layer responded substantially to litter manipulation, DOC of the mineral soil was insensitive to litter manipulation. This may be because DOC was quickly mineralized by soil microbial communities (Kalbitz et al., 2003) or adsorbed by the soil mineral matrix associated with soil organic matter (Kaiser and Guggenberger, 2000). Increasing fresh litter inputs could cause priming effects and lead to an increase in DOC flux from decomposing old soil C (Kalbitz et al., 2007). However, our analysis cannot distinguish whether the increase of DOC in the litter layer was a result of fresh litter inputs or the decomposition of old organic $\mathrm{C}$ in forest floor due to the priming effect.

\subsubsection{Total C}

The processes and mechanisms underlying the influence of fresh litter inputs on soil $\mathrm{C}$ dynamics are complex, involving the balance between $\mathrm{C}$ input and output and the turnover among different $\mathrm{C}$ pools (Kuzyakov, 2011). Additional inputs of fresh litter can cause priming effects, resulting in the mineralization of older soil organic matter (Sulzman et al., 2005; Sayer et al., 2007, 2011), which leads to the speculation that soil $\mathrm{C}$ storage may decrease under elevated litter inputs (Kuzyakov, 2010). Although there is ample evidence for the occurrence of priming effects under controlled conditions, the current lack of in situ studies of soil $\mathrm{C}$ release by priming precluded a quantitative analysis of the strength of priming effects in this study. However, our results showed that total $\mathrm{C}$ in the uppermost layers of the mineral soil generally increased with litter inputs (Fig. 1c). Hence, greater 
inputs of new organic $\mathrm{C}$ may compensate for the release of older soil organic C by priming (Talhelm et al., 2009; Hofmockel et al., 2011; Kuzyakov, 2011; Leff et al., 2012) suggesting that the soil acts as a net $\mathrm{C}$ sink under increased litter inputs. It remains to be seen if this "replacement" of older soil $\mathrm{C}$ with fresh $\mathrm{C}$ from increased litter inputs will have consequences for soil carbon stability in the longer term.

The response of soil $\mathrm{C}$ storage to litter manipulation differed among ecosystems (Table 2). (Sub-)tropical forest was more responsive to changes in litter production than other ecosystems, and total $\mathrm{C}$ in the mineral soil showed a greater reduction under litter removal. Field experiments in (sub-)tropical forests have also demonstrated that soil $\mathrm{C}$ pools responded rapidly to litter manipulation: soil $\mathrm{C}$ concentrations were significantly increased by $31 \%$ after only $2 \mathrm{yr}$ of litter addition in a tropical forest (Leff et al., 2012), whereas there was often no detectable change in soil $\mathrm{C}$ in temperate forest or grassland even after 5 to 11 years of elevated litter inputs (Nadelhoffer et al., 2004; Baer and Blair, 2008; Talhelm et al., 2009). There are several likely explanations for the notable responses of soil $\mathrm{C}$ in (sub-)tropical forest to litter manipulation: firstly, the duration of littermanipulation experiments in temperate or boreal biomes (28 yr; Fisk and Fahey, 2001; Fröberg et al., 2005; Sulzman et al., 2005) was often shorter than the mean residence time of the litter (4-16yr) in those ecosystems (Olson, 1963), whereas in (sub-)tropical forest, most of the $\mathrm{C}$ from fresh litter is rapidly mineralized and respired or transferred to the mineral soil. Secondly, the mean residence time of soil aggregate $\mathrm{C}$ in tropical forest is shorter than that in temperate forest (Six et al., 2002b), and new C inputs can be integrated into soil aggregates more rapidly, especially as tropical soils often have a high clay content and $\mathrm{C}$ from leachate can be bound easily into soil aggregates (Six et al., 2002a). Soil C concentration was therefore more likely to respond to altered litter inputs during the experimental period in (sub-)tropical forest (Leff et al., 2012).

In contrast to forest ecosystems, soil $\mathrm{C}$ in grasslands showed no significant responses to litter-manipulation treatments. Root-derived $\mathrm{C}$ is thought to be the main source of soil organic $\mathrm{C}$ in grasslands, and below-ground litter is thought to be more important for $\mathrm{C}$ sequestration (e.g. Steinbeiss et al. 2008). Further, a growing number of studies have shown that solar radiation, especially ultraviolet radiation, can be the dominant driver of litter decomposition in arid and semiarid regions (Austin and Vivanco, 2006; Brandt et al., 2007). For example, in a semi-arid steppe, Austin and Vivanco (2006) found that around $60 \%$ of C lost from aboveground litter was due to photochemical mineralization, resulting in a large proportion of litter-derived $\mathrm{C}$ being lost directly to the atmosphere without entering the soil.

We expected changes in total $\mathrm{C}$ in the mineral soil to become more pronounced with experimental duration. However, there was no significant effect of experimental duration on the responses of soil $\mathrm{C}$ pools to litter manipulation (Ta- ble A2 in the Supplement). This is possibly due to the high variation in mean residence times of $\mathrm{C}$ and litter decomposition rates among biomes (as discussed above), which makes it difficult to detect an effect of experimental duration when comparing studies across ecosystems.

\subsection{Nutrient cycling}

Litter is an important pathway for the transfer of nutrients from plants to soil, and the litter layer is critical for nutrient retention in some ecosystems. Our results suggest that total $\mathrm{N}$ and $\mathrm{C}: \mathrm{N}$ ratios, but not EIN, in the mineral soil increased with litter inputs. The lack of a clear overall response of EIN to litter manipulation was probably due to the contrasting responses of EIN in (sub-)tropical forest and temperate forest. EIN in the mineral soil declined significantly in (sub-)tropical forest under litter removal, but was unaffected in temperate forest (Table 3). Litter inputs were shown to be a significant source of EIN inputs to the mineral soil in (sub-)tropical forest (Sayer and Tanner, 2010), where rapid decomposition (Zhang et al., 2008) and high rates of leaching from the soil result in rapid turnover of mineral N. Consequently, when litter was removed, EIN in the mineral soil declined significantly. In contrast, the lower concentrations of EIN in temperate forests following litter addition may be a result of slower litter decomposition (Zhang et al., 2008) and greater immobilization of $\mathrm{N}$ in the mineral soil.

Plant growth in tropical forest is generally thought to be P-limited, and litter is the dominant P source to soil (Cleveland et al. 2011). It is therefore not surprising to find that litter removal reduced soil-extractable $\mathrm{P}$ in the mineral soil in (sub-)tropical forest (Table 3). Despite this, soil-extractable $\mathrm{P}$ of the mineral layer did not increase under litter addition in (sub-)tropical forest. For example, Sayer and Tanner (2010) found that, after a 5-year litter-manipulation study, litterderived $\mathrm{P}$ inputs significantly doubled under litter addition, but extractable $\mathrm{P}$ in the mineral soil did not change relative to the controls. This is probably due to direct uptake of litter-derived $\mathrm{P}$ by plant roots before it enters the mineral soil (Stark and Jordan, 1978; Herrera et al., 1978; Attiwill and Adams, 1993), in which case soil-extractable P would not increase under litter addition (Sayer and Tanner, 2010).

\section{Conclusions}

Global change alters not only the amount of above-ground litter inputs to soil but also other factors regulating soil $\mathrm{C}$ cycling. It is very difficult to separate the contribution of above-ground litter inputs to soil $\mathrm{C}$ and nutrient cycling from other drivers because the processes interact in complex ways. Litter-manipulation experiments therefore provide valuable information to estimate the effects of litter production on soil organic C formation (Sayer et al., 2011). 
With few exceptions, the direction of the responses was similar among terrestrial ecosystems for the investigated parameters, even though the magnitude of the responses varied (Fig. 1). Our meta-analysis of litter-manipulation experiments demonstrates that changes in total soil $\mathrm{C}$ and soil respiration are positively related to above-ground litter inputs, suggesting that the soil acts as a $\mathrm{C}$ sink even though $\mathrm{C}$ turnover is accelerated under greater litter inputs (Fig. 2). Compared to temperate forests, (sub-)tropical forests were generally more sensitive to litter-manipulation treatments; increases or decreases in litter inputs could therefore substantially alter the turnover and accumulation of soil $\mathrm{C}$ and nutrients in (sub-)tropical forests over a shorter time period (Leff et al., 2012). The critical role of tropical forests in regulating atmospheric $\mathrm{CO}_{2}$ has been widely recognized. However, much attention has been focused on $\mathrm{C}$ stored in the vegetation rather than tropical forest soils. A number of studies have demonstrated that global change has stimulated aboveground net primary production (ANPP) in tropical forests over recent decades (Lewis et al., 2009; Pan et al., 2011). Although soil $\mathrm{C}$ accumulation may be lower than expected because of C release by priming effects (Sayer et al., 2011), we predict that tropical forest soils will act as a $\mathrm{C}$ sink alongside the increased ANPP under global change (Table 2). However, the current lack of long-term monitoring of tropical soil C dynamics makes it difficult to determine the $\mathrm{C}$ sequestration capacity of tropical forest soils.

Litter manipulation not only directly alters $\mathrm{C}$ and nutrient cycling by providing substrates to soil microbes, it also indirectly changes $\mathrm{C}$ cycling by modifying soil physicochemical conditions (Sayer, 2006), which is especially important in grasslands (Wang et al., 2011). Although litter addition had little effect on soil C storage in grasslands, above-ground litter inputs appear to play a critical role in maintaining favourable soil conditions by buffering soil temperature and moisture.

Altered litter production caused by environmental change could lead to cascading effects on soil physicochemical properties, $\mathrm{C}$ dynamics and nutrient cycling (Fig. 2). Overall, our study suggests that increases in litter inputs generally accelerated the rates of below-ground biogeochemical reactions and transformations, whereas decreased litter inputs reduced them. The ensuring feedbacks between altered above-ground productivity and changes in below-ground biogeochemical processes need to be considered for predicting ecosystem responses to global change.

\section{Supplementary material related to this article is available online at http://www.biogeosciences.net/10/ 7423/2013/bg-10-7423-2013-supplement.zip.}

Acknowledgements. This study was supported financially by the National Natural Science Foundation of China (13263A1001), Chinese National Key Development Program for Basic Research (2013CB956304) and National 1000 Young Talents Program.

Edited by: R. Conant

\section{References}

Adams, D. C., Gurevitch, J., and Rosenberg, M. S.: Resampling tests for meta-analysis of ecological data, Ecology, 78, 12771283, doi:10.1890/00129658(1997)078[1277:rtfmao]2.0.co;2, 1997.

Amatangelo, K. L., Dukes, J. S., and Field, C. B.: Responses of a California annual grassland to litter manipulation, J. Vegetat. Sci., 19, 605-612, doi:10.3170/2008-8-18415, 2008.

Attiwill, P. M. and Adams, M. A.: Nutrient Cycling in Forests, New Phytologist, 124, 561-582, 1993.

Austin, A. T. and Vivanco, L.: Plant litter decomposition in a semiarid ecosystem controlled by photodegradation, Nature, 442, 555-558, doi:10.1038/nature05038, 2006.

Baer, S. G. and Blair, J. M.: Grassland Establishment under Varying Resource Availability: A Test of Positive and Negative Feedback, Ecology, 89, 1859-1871, doi:10.1890/07-0417.1, 2008.

Brandt, L. A., King, J. Y., and Milchunas, D. G.: Effects of ultraviolet radiation on litter decomposition depend on precipitation and litter chemistry in a shortgrass steppe ecosystem, Glob. Change Biol., 13, 2193-2205, doi:10.1111/j.1365-2486.2007.01428.x, 2007.

Chapin, F. S., Matson, P. A., and Vitousek, P. M.: Principles of Terrestrial Ecosystem Ecology, Springer, doi:10.1007/978-1-44199504-9, 2011.

Cleveland, C. C., Townsend, A. R., and Schmidt, S. K.: Phosphorus Limitation of Microbial Processes in Moist Tropical Forests: Evidence from Short-Term Laboratory Incubations and Field Studies, Ecosystems, 5, 680-691, doi:10.1007/s10021-002-0202-9, 2002.

Cleveland, C. C., A. R. Townsend, P. Taylor, S. Alvarez-Clare, M. M. C. Bustamante, G. Chuyong, S. Z. Dobrowski, P. Grierson, K. E. Harms, B. Z. Houlton, A. Marklein, W. Parton, S. Porder, S. C. Reed, C. A. Sierra, W. L. Silver, E. V. J. Tanner, and W. R. Wieder.: Relationships among net primary productivity, nutrients and climate in tropical rain forest: a pan-tropical analysis, Ecology Lett., 14, 939-947, doi:10.1111/j.1461-0248.2011.01711.x, 2011.

Dzwonko, Z. and Gawronski, S.: Effect of litter removal on species richness and acidification of a mixed oak-pine woodland, Biol. Conserv., 106, 389-398, doi:10.1016/S0006-3207(01)00266-X, 2002.

Fisk, M. C. and Fahey, T.: Microbial biomass and nitrogen cycling responses to fertilization and litter removal in young northern hardwood forests, Biogeochemistry, 53, 201-223, doi:10.1023/A:1010693614196, 2001.

Fontaine, S., Bardoux, G., Abbadie, L., and Mariotti, A.: Carbon input to soil may decrease soil carbon content, Ecology Letters, 7, 314-320, doi:10.1111/j.1461-0248.2004.00579.x, 2004.

Fornara, D. A. and Tilman, D.: Soil carbon sequestration in prairie grasslands increased by chronic nitrogen addition, Ecology, 93, 2030-2036, doi:10.1890/12-0292.1, 2012. 
Fröberg, M., Kleja, D. B., Bergkvist, B., Tipping, E., and Mulder, J.: Dissolved Organic Carbon Leaching from a Coniferous Forest Floor - A Field Manipulation Experiment, Biogeochemistry, 75, 271-287, doi:10.1007/s10533-004-7585-y, 2005.

Fu, R., Gartlehner, G., Grant, M., Shamliyan, T., Sedrakyan, A., Wilt, T. J., Griffith, L., Oremus, M., Raina, P., Ismaila, A., Santaguida, P., Lau, J., and Trikalinos, T. A.: Conducting quantitative synthesis when comparing medical interventions: AHRQ and the Effective Health Care Program, Journal of clinical epidemiology, 64, 1187-1197, doi:10.1016/j.jclinepi.2010.08.010, 2011.

Hedges, L. V., Gurevitch, J., and Curtis, P. S.: The meta-analysis of response ratios in experimental ecology, Ecology, 80, 1150-1156, doi:10.1890/00129658(1999)080[1150:TMAORR]2.0.CO;2, 1999.

Herrera, R., Merida, T., Stark, N., and Jordan, C. F.: Direct Phosphorus Transfer from Leaf Litter to Roots, Naturwissenschaften, 65, 208-209, doi:10.1007/BF00450594, 1978.

Hofmockel, K. S., Zak, D. R., Moran, K. K., and Jastrow, J. D.: Changes in forest soil organic matter pools after a decade of elevated CO2 and O3, Soil Biol. Biochem., 43, 1518-1527, doi:10.1016/j.soilbio.2011.03.030, 2011.

Hungate, B. A., Jackson, R. B., Field, C. B., and III, F. S. C.: Detecting changes in soil carbon in $\mathrm{CO} 2$ enrichment experiments, Plant Soil, 187, 135-145, doi:10.1007/BF00017086, 1996.

Irving, P. M. and Miller, J. E.: Productivity of field-grown soybeans exposed to acid rain and sulfur dioxide alone and in combination, Journal Name: J. Environ. Qual., 10:4, 473-478, doi:10.2134/jeq1981.00472425001000040010x, 1981.

Kaiser, K. and Guggenberger, G.: The role of DOM sorption to mineral surfaces in the preservation of organic matter in soils, Organic Geochemistry, 31, 711-725, doi:10.1016/S01466380(00)00046-2, 2000.

Kalbitz, K., Schmerwitz, J., Schwesig, D., and Matzner, E.: Biodegradation of soil-derived dissolved organic matter as related to its properties, Geoderma, 113, 273-291, doi:10.1016/s0016-7061(02)00365-8, 2003.

Kalbitz, K., Meyer, A., Yang, R., and Gerstberger, P.: Response of dissolved organic matter in the forest floor to long-term manipulation of litter and throughfall inputs, Biogeochemistry, 86, 301318, doi:10.1007/s10533-007-9161-8, 2007.

King, J. S., Kubiske, M. E., Pregitzer, K. S., Hendrey, G. R., McDonald, E. P., Giardina, C. P., Quinn, V. S., and Karnosky, D. F.: Tropospheric $\mathrm{O}_{3}$ compromises net primary production in young stands of trembling aspen, paper birch and sugar maple in response to elevated atmospheric $\mathrm{CO}_{2}$, The New phytologist, 168, 623-636, doi:10.1111/j.1469-8137.2005.01557.x, 2005.

Kuzyakov, Y.: Priming effects: Interactions between living and dead organic matter, Soil Biology and Biochemistry, 42, 1363-1371, doi:10.1016/j.soilbio.2010.04.003, 2010.

Kuzyakov, Y.: Ecology: Prime time for microbes, Nature Climate Change, 1, 295-297, doi:10.1038/nclimate1194, 2011.

Leff, J. W., Wieder, W. R., Taylor, P. G., Townsend, A. R., Nemergut, D. R., Grandy, A. S., and Cleveland, C. C.: Experimental litterfall manipulation drives large and rapid changes in soil carbon cycling in a wet tropical forest, Glob. Change Biol., 18, 2969-2979, doi:10.1111/j.1365-2486.2012.02749.x, 2012.

Lewis, S. L., Lloyd, J., Sitch, S., Mitchard, E. T. A., and Laurance, W. F.: Changing Ecology of Tropical Forests: Evidence and Drivers, Annual Review of Ecology, Evolution, and Systematics,
40, 529-549, doi:10.1146/annurev.ecolsys.39.110707.173345, 2009.

Liu, L., King, J. S., and Giardina, C. P.: Effects of elevated concentrations of atmospheric $\mathrm{CO} 2$ and tropospheric $\mathrm{O}_{3}$ on leaf litter production and chemistry in trembling aspen and paper birch communities, Tree Physiology, 25, 1511-1522, doi:10.1093/treephys/25.12.1511, 2005.

Liu, L., King, J. S., Booker, F. L., Giardina, C. P., Lee Allen, H., and $\mathrm{Hu}, \mathrm{S}$.: Enhanced litter input rather than changes in litter chemistry drive soil carbon and nitrogen cycles under elevated $\mathrm{CO}_{2}$ : a microcosm study, Global Change Biology, 15, 441-453, doi:10.1111/j.13652486.2008.01747.x, 2009.

Lowman, M. D. and Schowalter, T. D.: Plant science in forest canopies-the first 30 years of advances and challenges (19802010), The New phytologist, 194, 12-27, doi:10.1111/j.14698137.2012.04076.x, 2012

Nadelhoffer, K. J., Boone, R. D., Bowden, R. D., Canary, J. D., Kaye, J., Micks, P., Ricca, A., Aitkenhead, J. A., Lajtha, K., and McDowell, W. H.: Litter and Root Influences on Forest Soil Organic Matter Stocks and Function, Oxford University Press, Chapter 15, 2004

Olson, J. S.: Energy Storage and the Balance of Producers and Decomposers in Ecological Systems, Ecology, 44, 322-331, doi:10.2307/1932179, 1963.

Ostertag, R., Scatena, F. N., and Silver, W. L.: Forest Floor Decomposition Following Hurricane Litter Inputs in Several Puerto Rican Forests, Ecosystems, 6, 261-273, doi:10.1007/s10021-0020203-8, 2003.

Pan, Y., Birdsey, R. A., Fang, J., Houghton, R., Kauppi, P. E., Kurz, W. A., Phillips, O. L., Shvidenko, A., Lewis, S. L., Canadell, J. G., Ciais, P., Jackson, R. B., Pacala, S. W., McGuire, A. D., Piao, S., Rautiainen, A., Sitch, S., and Hayes, D.: A large and persistent carbon sink in the world's forests, Science, 333, 988993, doi:10.1126/science.1201609, 2011.

Park, J.-H. and Matzner, E.: Detrital control on the release of dissolved organic nitrogen (DON) and dissolved inorganic nitrogen (DIN) from the forest floor under chronic $\mathrm{N}$ deposition, Environmental Pollution, 143, 178-185, doi:10.1016/j.envpol.2005.10.045, 2006.

Raich, J. W., Russell, A., Kitayama, K., Parton, W. J., and Vitousek, P. M.: Temperature influences carbon accumulation in moist tropical forests, Ecology, 87, 76-87, doi:10.1890/05-0023, 2006.

Sayer, E. J.: Using experimental manipulation to assess the roles of leaf litter in the functioning of forest ecosystems, Biol. Rev., 81, 1-31, doi:10.1017/s1464793105006846, 2006.

Sayer, E. J. and Tanner E. V. J.: A new approach to trenching experiments for measuring root-rhizosphere respiration in a lowland tropical forest. Soil Biology and Biochemistry, 42, 347-352, 2010.

Sayer, E. J. and Tanner, E. V. J.: Experimental investigation of the importance of litterfall in lowland semi-evergreen tropical forest nutrient cycling, J. Ecol., 98, 1052-1062, doi:10.1111/j.13652745.2010.01680.x, 2010.

Sayer, E. J., Powers, J. S., and Tanner, E. V. J.: Increased Litterfall in Tropical Forests Boosts the Transfer of Soil $\mathrm{CO}_{2}$ to the Atmosphere, PLoS ONE, 2, doi:10.1371/journal.pone.0001299.g002, 2007. 
Sayer, E. J., Heard, M. S., Grant, H. K., Marthews, T. R., and Tanner, E. V. J.: Soil carbon release enhanced by increased tropical forest litterfall, Nature, 1, 304-307, doi:10.1038/nclimate119010.1038/NCLIMATE1190, 2011.

Schmidt, M. W. I., Torn, M. S., Abiven, S., Dittmar, T., Guggenberger, G., Janssens, I. A., Kleber, M., Kogel-Knabner, I., Lehmann, J., Manning, D. A. C., Nannipieri, P., Rasse, D. P., Weiner, S., and Trumbore, S. E.: Persistence of soil organic matter as an ecosystem property, Nature, 478, 49-56, doi:10.1038/nature10386, 2011.

Six, J., Conant, R. T., Paul, E. A., and Paustian, K.: Stabilization mechanisms of soil organic matter: Implications for C-saturation of soils, Plant and Soil, 241, 155-176, doi:10.1023/A:1016125726789, 2002a.

Six, J., Feller, C., Denef, K., Ogle, S. M., de Moraes, J. C., and Albrecht, A.: Soil organic matter, biota and aggregation in temperate and tropical soils - Effects of no-tillage, Agronomie, 22, 755-775, doi:10.1051/agro:2002043, 2002b.

Stark, N. M. and C. F. Jordan.: Nutrient retention by root mat of an Amazonian rain-forest, Ecology, 59, 434-437, doi:10.2307/1936571, 1978.

Steinbeiss, S., Bessler, H., Engels, C., Temperton, V. M., Buchmann, N., Roscher, C., Kreutziger, Y., Baade, J., Habekost, M., and Gleixner, G.: Plant diversity positively affects short-term soil carbon storage in experimental grasslands, Glob. Change Biol., 14, 2937-2949, 2008.

Sulzman, E. W., Brant, J. B., Bowden, R. D., and Lajtha, K.: Contribution of aboveground litter, belowground litter, and rhizosphere respiration to total soil $\mathrm{CO}_{2}$ efflux in an old growth coniferous forest, Biogeochemistry, 73, 231-256, doi:10.1007/s10533-0047314-6, 2005.
Talhelm, A. F., Pregitzer, K. S., and Zak, D. R.: Species-specific responses to atmospheric carbon dioxide and tropospheric ozone mediate changes in soil carbon, Ecol. Lett., 12, 1219-1228, doi:10.1111/j.1461-0248.2009.01380.x, 2009.

Tian, D. L., Peng, Y. Y., Yan, W. D., Fang, X., Kang, W. X., Wang, G. J., and Chen, X. Y.: Effects of Thinning and Litter Fall Removal on Fine Root Production and Soil Organic Carbon Content in Masson Pine Plantations, Pedosphere, 20, 486-493, doi:10.1016/S1002-0160(10)60038-0, 2010.

Wang, J., Zhao, M., Willms, W. D., Han, G., Wang, Z., and Bai, Y.: Can plant litter affect net primary production of a typical steppe in Inner Mongolia?, J. Vegetat. Sci., 22, 367-376, doi:10.1111/j.1654-1103.2011.01257.x, 2011.

Wardle, D. A.: A comparative assessment of factors which influence microbial biomass carbon and nitrogen levels in soil, Biol. Rev., 67, 321-358, doi:10.1111/j.1469-185X.1992.tb00728.x, 1992.

Wardle, D. A., Hornberg, G., Zackrisson, O., Kalela-Brundin, M., and Coomes, D. A.: Long-Term Effects of Wildfire on Ecosystem Properties Across an Island Area Gradient, Science, 300, 972 975, doi:10.1126/science.1082709, 2003.

Wieder, R. K. and Wright, S. J.: Tropical Forest Litter Dynamics and Dry Season Irrigation on Barro Colorado Island, Panama, Ecology, 76, 1971-1979, doi:10.2307/1940727, 1995.

Xia, J. and Wan, S.: Global response patterns of terrestrial plant species to nitrogen addition, New Phytologist, 179, 428-439, doi:10.1111/j.1469-8137.2008.02488.x, 2008.

Zhang, D., Hui, D., Luo, Y., and Zhou, G.: Rates of litter decomposition in terrestrial ecosystems: global patterns and controlling factors, J. Plant Ecol., 1, 85-93, doi:10.1093/jpe/rtn002, 2008.

Zhao, M. and Running, S. W.: Drought-induced reduction in global terrestrial net primary production from 2000 through 2009 , Science, 329, 940-943, doi:10.1126/science.1192666, 2010. 